\title{
IAMJ
}

INTERNATIONAL

AYURVEDIC

MEDICAL JOURNAL

\section{CLINICAL STUDY ON SHIREESHADI AVAPEEDANA NASYA IN THE MANAGEMENT OF SURYAVARTHA (FRONTAL SINUSITIS)}

\section{Amarnath H K}

Associate Professor, Department of Shalakya Tantra, Shri Dharmasthala Manjunatheshwara College of Ayurveda and Hospital, Hassan - 573201 Karnataka, India

Corresponding Author:amarnath.hk@gmail.com

\section{https://doi.org/10.46607/iamj0909082021}

(Published Online: August 2021)

Open Access

(C) International Ayurvedic Medical Journal, India 2021

Article Received:18/07//2021 - Peer Reviewed:21/07/2021 - Accepted for Publication:22/07/2021

\section{Check for updates}

\begin{abstract}
Nasya karma is considered a prime treatment modality in all types of Shiroroga (Headache) and also in Suryavartha (Frontal Sinusitis). Suryavartha (Frontal Sinusitis) is one of the 11 types of Shiroroga. It is one of the common clinical conditions found in day to day general as well as Shalakya (ENT) practice. It presents with headache as one of its cardinal features and its occurrence is found in both genders and in all age groups. Objective: To study the efficacy of Shireeshadi Avapeedana Nasya in the management of Suryavartha (Frontal Sinusitis). Material methods: Twenty patients of Suryavartha (Frontal Sinusitis) were diagnosed and registered for the clinical study irrespective of sex, socio-economic status, and religion. The study was divided into two groups - Group A and Group B. Group - A patients were treated with Shireeshadi Avapeedana Nasya for 7 days and Group - B patients were treated by Nasya with milk for 7 days. Observation and result: Among 20 patients of Suryavartha / frontal sinusitis, 20 (100\%) of patients had headache, 11 (55\%) had nasal blockage, 05 (25\%) had nasal discharge, 08 (40\%) had foul smell in their breath and 14 (70\%) have variations from normal X-Ray. The severity of headache is significantly reduced after treatment in both Groups A and B (92.95\% and 73.07\%) respectively. Conclusion: Administration of Shireeshadi Avapeeda Nasya showed statistically significant improvement in the management of Suryavartha (Frontal Sinusitis).
\end{abstract}


Keywords: Suryavartha, Nasya, Shireeshadi Avapeedana Nasya, Frontal Sinusitis, Shigru, Mulaka, Ksheera.

\section{INTRODUCTION}

Suryavartha (Frontal Sinusitis) is one among the Visesha Shiroroga. It has a particular periodicity that follows the sun and is considered as a Kastatama Vyadhi, meaning which gives severe distress to the patient. ${ }^{1}$ Classification Nasya has few salient features, and each is done with different aspects. Avapeeda Nasya is a procedure where Swarasa (expressed juice) of the prescribed drugs are administered directly into the nostril. Depending upon the drug used, Avapeeda Nasya is administered for Shodhana and Shaman. ${ }^{2}$ The cardinal features of Suryavartha are, pain in Shiras which gradually increases as the intensity of the sun increases and comes down by evening. The symptoms may sometimes be relived either by cold or warm substances or surroundings and Hunger may aggravate the pain. ${ }^{3}$ References of few simple techniques and medicaments are available for the management of Suryavartha and Shireeshadi Avapeedana Nasya ${ }^{4}$ is one of them advocated by Acharya Chakrapannidatta and was selected for the trial group and Nasya with milk in control group.

\section{Objective}

- To evaluate the effect of Shireeshadi avapeedana (trail drug) Nasya in the management of Suryavartha.

- To evaluate the effect of Nasya with milk (control drug) in the management of Suryavartha.

\section{Materials And Methods}

A total of 20 patients were selected randomly from the out-patient department of Shalakya Tantra, Shri Dharmasthala Manjunatheshwara College of Ayurveda and Hospital, Hassan.

\section{Inclusion criteria}

Patients presenting with the clinical features of Suryavartha (Frontal Sinusitis) between the age group of 16 to $60 \mathrm{yrs}$ were selected. Patients were selected irrespective of gender, occupation, religion, socioeconomic status and duration of illness.

\section{Exclusion criteria}

Patients with notable Systemic as well as Neurological problems and known patients with the complica- tion of Frontal Sinusitis such as Orbital cellulites, Osteomyelitis of frontal bone were excluded.

Study Design: 20 Patients were divided into 2 groups of 10 each. Group A - 6 drops of Shireeshadi Avapeedana Nasya was administered before food in each nostril for seven days, once daily in the morning. Group B - 6 drops of Nasya with milk was administered before food in each nostril for seven days, once daily in the morning. Both groups were followed at regular intervals of 1 month for two months.

\section{Method of administration of Avapeeda Nasya ${ }^{5}$ Purvakarma}

Nasya was performed in a place having sufficient light and devoid of direct blowing wind and dust. The patient was asked to sleep comfortably in supine position on a table and Abhyanga (Massage) with lukewarm Taila (Oil) was done over the face, scalp, neck and temporal region. After completion of Abhyanga, Mrudu Svedana (Mild fomentation) was done by covering the eyes.

Pradhanakarma: After proper completion of Purvakarma, the patient was asked to relax and lie down on a table in the supine position and the head portion was made to extend further from the edge of the table bending slightly down at an angle with limbs kept slightly spread apart on both sides. Kalka of Shirishadi Avapeeda Nasya / Milk (depending on the group) was taken over on a piece of cloth / by a cotton swab respectively and six drops are administered in each nostril. Thereafter patient was asked to inhale deeply and was advised to spit out the drug that reaches the throat.

Pashchatkarma: After performing the Pradhana Karma, the patient was allowed to come to ease in the supine position. Again, massage and fomentation with palms were done around the face, nose, head, neck, and chin. It was advised to spit out nasal secretion reaching the throat and to do gargle with warm water. After this, the patient was instructed neither to take cold food / water nor to wash face with cold water and was also asked to avoid wind and dust. 


\section{OBSERVATIONS AND RESULTS}

Age-wise distribution of patients: 12 patients (60\%) were in the age group of $16-30 \mathrm{yrs}, 7$ patients $(35 \%)$ were in the age group of $31-45$ yrs and 01 patient $(05 \%)$ was between the age of group $46-60 \mathrm{yrs}$.

Distribution of Nidanas: out of 20 patients, 09 (45\%) had exposure with Avashaya, 09 (45\%) with Pragvata, 14 (70\%) Raja Sevana, 14 (70\%) with Dhooma Sevana, 02 (10\%) with Ambukrida, 02 (10\%) had Pratishaya and 01 (05\%) had suffered from flu. Severity wise distribution of headache: out of 20 patients, $13(65 \%)$ had severe and 07 (35\%) patients had a moderate form of headache. Chronicity wise distribution of Suryavartha: out of 20 patients, 3 patients (15\%) had the history with less than a month, 07 patients $(35 \%)$ since 1 to $3 \mathrm{~m}, 03$ patients (15\%) since 4 to $6 \mathrm{~m}, 04$ patients $(20 \%)$ since 7 to $12 \mathrm{~m}$ and 03 patients $(15 \%)$ with history of headache for more than a year.
Incidences of Symptoms: Among 20, all 20 (100\%) of patients had headache, $11(55 \%)$ had nasal blockage, $05(25 \%)$ had nasal discharge, $08(40 \%)$ had foul smell in their breath and $14(70 \%)$ have variations from normal X-Ray.

Distribution of nasal anomalies: out of 20 patients, $06(30 \%)$ had only congested nasal mucosa, $05(25 \%)$ had only hypertrophied turbinate, 03 (15\%) had congested nasal mucosa with the deviated nasal septum, $01(05 \%)$ had congested nasal mucosa with hypertrophied turbinate, 02 (10\%) had deviated nasal septum with hypertrophied turbinate, $02(10 \%)$ had nasal polyps with a deviated nasal septum and $01(05 \%)$ had Nasal polyps with congested nasal mucosa.

\section{RESULTS}

' $t$ ' test results of the difference between the means of the two dependent samples (before and after treatment) in reduction of severity of the headache in Group A and Group B.

\begin{tabular}{|c|c|c|c|c|c|c|c|c|c|c|}
\hline \multicolumn{2}{|c|}{ Headache } & \multicolumn{2}{|c|}{ Mean score } & $\begin{array}{l}\text { Reduction } \\
\text { in mean } \\
\text { score }\end{array}$ & $\begin{array}{l}\% \text { of reduction } \\
\text { in mean score }\end{array}$ & $\begin{array}{l}\text { S.D of } \\
\text { mean }\end{array}$ & $\begin{array}{l}\text { S.E of } \\
\text { mean }\end{array}$ & df & $\begin{array}{l}\text { 't' } \\
\text { Value }\end{array}$ & 'p' Value \\
\hline $\begin{array}{l}\mathrm{G} \\
\mathrm{R}\end{array}$ & $\begin{array}{l}\text { After } 7 \text { days of } \\
\text { treatment }\end{array}$ & $\begin{array}{l}\text { BT } \\
2.7\end{array}$ & \begin{tabular}{|l|} 
AT \\
0.2
\end{tabular} & 2.5 & 92.59 & 0.7071 & 0.2236 & 9 & 11.18 & $<0.001$ \\
\hline $\begin{array}{l}\mathrm{O} \\
\mathrm{U}\end{array}$ & $\begin{array}{l}\text { Follow up after } \\
1 \text { month }\end{array}$ & 2.7 & 0.1 & 2.6 & 96.29 & 0.6992 & 0.2211 & 9 & 11.75 & $<0.001$ \\
\hline A & $\begin{array}{l}\text { Follow up after } \\
2 \text { months }\end{array}$ & 2.7 & 0.5 & 2.2 & 81.48 & 1.0327 & 0.3265 & 9 & 6.738 & $<0.001$ \\
\hline $\begin{array}{l}\mathrm{G} \\
\mathrm{R}\end{array}$ & $\begin{array}{l}\text { After } 7 \text { days of } \\
\text { treatment }\end{array}$ & 2.6 & 0.7 & 1.9 & 73.07 & 0.7378 & 0.2333 & 9 & 8.144 & $<0.001$ \\
\hline $\begin{array}{l}\mathrm{O} \\
\mathrm{U}\end{array}$ & $\begin{array}{l}\text { Follow up after } \\
1 \text { month }\end{array}$ & 2.6 & 0.5 & 2.1 & 80.76 & 0.9944 & 0.3144 & 9 & 6.679 & $<0.001$ \\
\hline B & $\begin{array}{l}\text { Follow up after } \\
2 \text { months }\end{array}$ & 2.6 & 0.8 & 1.8 & 69.23 & 1.2292 & 0.3887 & 9 & 4.630 & $<0.01$ \\
\hline
\end{tabular}

In group A, the reduction in mean severity of the headache is,

- Before and after treatment shows changes from 2.7 to 0.2 showing a reduction of $2.5(92.59 \%)$ which is statistically significant at the level of $\mathrm{p}<0.001$,

- Changes after $1^{\text {st }}$ month follow up is from 2.7 to 0.1 showing a reduction of $2.6(96.29 \%)$ which is statistically significant at the level of $p<0.001$ and

- Changes after $2^{\text {nd }}$ month follow up is from 2.7 to 0.5 showing a reduction of $2.2(81.48 \%)$ which is statistically significant at the level of $\mathrm{P}<0.001$. 


\section{In group B, the reduction in mean severity of the headache is:}

- Before and after treatment shows changes from 2.6 to 0.7 showing a reduction of $1.9(73.07 \%)$ which is statistically significant at the level of $\mathrm{P}$ $<0.001$.

- Changes after $1^{\text {st }}$ month follow up is from 2.6 to 0.5 showing a reduction of $2.1(80.76 \%)$ which is statistically significant at the level of $\mathrm{P}<0.001$ and

- Changes after $2^{\text {nd }}$ month follow up is from 2.6 to 0.8 showing a reduction of $1.8(69.23 \%)$ which is statistically significant at the level of $\mathrm{P}<0.01$.

\section{DISCUSSION}

Etiopathology, clinical features and prognosis of Suryavartha (Frontal Sinusitis) resemble frontal sinusitis. Selected patients were categorized under two groups. Out of which, the first group of patients were administered with Shireshadi Avapeeda Nasyaand in the second group, Nasya with milk was administered. For this purpose, a need for the control group was taught either with a placebo or with a standard drug. Search for a suitable placebo was difficult because Neera (water), Ksheera (milk), Narikelajala (coconut water) and Sarpi (ghee) are indicated with Sarkara (Sugar) for Nasya in Suryavartha. There are various references regarding the usage of milk exclusively in different forms for Suryavartha. It is used as Ksheera Vikruti (edibles made of milk), Ksheerasarpi Pana (intake of milk with ghee), Ksheerasarpi Nasya (administration of milk with ghee for Nasya), Sharkaraksheera Nasya (milk with sugar for Nasya) etc., As there is no authenticated or proven standard drug which can be used as a controlled drug and considering therapeutic importance given to milk in Suryavartha, milk was taken for the comparison as a controlled drug for Nasya in this study. Occupation wise distribution noted that Suryavartha (Frontal Sinusitis) is prevalent in those who work in or who in due course of their work get exposed to dust, wind and extreme atmospheric conditions. By these, we can infer that the working environment (occupation) plays an important role in causing Suryavartha. In this study, it is noted that in a few of the patients, Pratishayaya (20\%) and flu (15\%) acted as a $\mathrm{Ni}$ dhanakara Roga (predisposing factor) in the manifestation of Suryavartha. This observation supports a study stating, "Viral infection due to flu and rhinitis is the precursor to sinusitis. ${ }^{7}$ Acharya Kashyapa in the context of Pratishyaya Chikitsa has stated that a person suffering from Pratishyaya if consumes Ushna, Teekshna, Amla and Lanava Ahara in excess causes Pitta Prakopa and leads to Suryavartha. ${ }^{8}$ So, Pratishyaya and flu/cold can be established as the predisposing factor in Suryavartha.

Shireeshadi Avapeedana Nasya is administered as Nasya in Group A. The contents in it are Shireesha Valkala and Mulaka Beeja which were made into Kalka using water for the extraction of Swarasa and this Swarasa was used for Nasya Karma. In group B, Nasya with milk was administered. Both Swarasa and milk were found non-irritant, as none of the patients complained of any adverse effect or irritation from the drug. Shirisha has the properties such as Vedanasthapana, Shotahara and is Tridoshashamaka. Vijayarakshita in his commentary states that drugs like Sirisha, Pippali, Vacha are used for Avapeeda Nasya in Suryavartha as they are Vyadhi Pratyanika Dravyas. The properties in the bark of Albizia lebbeck are said to be anti-allergic and antimicrobial. Various studies have been conducted to study its anti-allergic, antimicrobial and immunological properties. According to Ayurveda, Mulaka Beeja has the properties such as Tridoshashamaka and Nasikarogagna. The seeds of Raphanus sativus contain raphanin; it has antibacterial activity against a wide range of bacteria. ${ }^{9}$ Ivanovics G. et al for the first time isolated this property in 1947. It acts antimicrobial, antifungal and expectorant. Properties of milk as per Ayurveda are Vata Pitta Shamaka, Bruhmana and Shotahara. Several proteins found in milk under various conditions exhibit antimicrobial activity. Four of such proteins have an active role, lactoferrin, lactoperoxidase, lysozyme, and N-acetyl- $\beta-D-$ glucosaminidase (NAGase) in antimicrobial activity. ${ }^{10}$ In Nasya Karma, the procedures such as Snehana and Swedana constitute the Poorvakarma; 
these have the properties such as Dosha Viliyana, Jadyahara, Sthabdagna and Ruk Prashamana. Stem inhalation helps to reduce the pain and irritation of the somatic constriction and enhances the drug absorption due to heat stimulation by local fomentation and vasodilatation. The Pradhanakarma constitutes, administration of the drug to Nasa, they act on their own accord depending on the properties of the drug in them. Thus, the above-mentioned drugs and the procedures have the properties to cheek the pathology as per Ayurveda in Suryavartha (Frontal Sinusitis) and also in terms of contemporary science for frontal sinusitis. The severity of headache is significantly reduced after treatment in both groups A and group B i.e., $92.95 \%$ and $73.07 \%$ respectively. The ' $p$ ' value of both the groups gives a significant result at a level of $p<0.001$. However, in Group - A percentage of relief from the severity of headache is more significant compared with Group - B. This data indicates that Shirishadi Avapeeda Nasya is more effective in reducing the severity of headache than milk. At the end of the second month follow up, it is observed that, among 10 patients with headache in Group - A, 06 patients have complete relief, 02 patients have marked relief, 01 had moderate relief and recurrence is seen in 01 patient. Among 10 in Group - B, 04 patients have complete relief, 01 had marked relief, 02 have moderate relief, 01 had mild relief and recurrence is seen in 02 patients.

It indicates that Shirishadi Avapeeda Nasya is found effective throughout the follow up of two months than by Nasya with milk in Suryavartha.

\section{CONCLUSION}

Nasya Karma is a prime treatment modality in all types of Shiroroga. Suryavartha (Frontal Sinusitis) is one of the eleven types of Shiroroga. Suryavartha is one of the common clinical conditions found in day to day general as well as Shalakya (ENT) practice. Administration of Shireeshadi Avapeeda Nasya showed statistically significant improvement in the management of Suryavartha (Frontal Sinusitis).

\section{REFERENCES}

1. Shashirekha H K, Bargale S S, editor.Charaka Samhita Sanskrit text with English translation, Sutrasthana, chapter 17, Kiyanta Shiraseeya Adhyaya, verse no. 8-10. $1^{\text {ste }}$ dition, Varanasi; ChowkhambhaSanskritSansthana; 2017; p.266-267.

2. Yadavaji Trikamji, editor. Commentary: NibandhaSangraha of Dalhana on Sushruta Samhita of Sushruta, Chikitsa sthana, chapter40, Dhuma Nasya Kavalagraha Chikitsitam Adhyaya,verse no. 21-29. Reprint 2013, Varanasi; Chaukhambha Orientalia; p.554

3. Yadavaji Trikamji, editor. Commentary: NibandhaSangraha of Dalhana on Sushruta Samhita of Sushruta, Uttara Tantra, chapter 25, Shiroroga Vigjnaniya Adhyaya, verse no. 11-12. Reprint 2013, Varanasi; Chaukhambha Orientalia; p.655

4. Sharma P V. Chakradatta text with English translation. Chapter 60, Shiro Roga Chikitsa Adhyaya, verse no 45, First edition, Chaukhamba orientalia, Varanasi. 1994.p. 520

5. Shashirekha H K, Bargale S S, editor. Charaka Samhita Sanskrit text with English translation, Siddhi sthana, chapter 9, Trimarmiya Adhyaya, verseno. 79. 1st edition, Varanasi; Chowkhambha SanskritSansthana; 2018; p.280-281.

6. Yadavaji Trikamji, editor. Commentary: NibandhaSangraha of Dalhana on Sushruta Samhita of Sushruta, Uttara Tantra, chapter 26, Shiroroga Pratishedhama Adhyaya, verse no. 30. Reprint 2013, Varanasi; Chaukhambha Orientalia; 2013; p657

7. Pratter MR. Cough and the common cold: ACCP evidence-based clinical practice guidelines. Chest. 2006 Jan 1;129(1):72S-4S.

8. Tewari PV. Kashyapasamhita. Chikitsa Sthana, chapter 12, Pratishyaya Chikitsa Adhyaya, verse no 05. Reprint 2008, Chaukhamba Visvabharati, Varanasi. 2008. Page no-222

9. Ivánovics G, Horváth S. Raphanin, an antibacterial principle of the radish (Raphanus sativus). Nature. 1947 Aug;160(4061):297-8.

10. Losnedahl KJ, Wang H, Aslam M, Zou S, Hurley WL. Antimicrobial factors in milk. Illini DairyNet Papers. 1998; 38:1-4.

\section{Source of Support: Nil \\ Conflict of Interest: None Declared}

How to cite this URL: Amarnath $\mathrm{H} \mathrm{K}$ et al: Clinical Study On Shireeshadi Avapeedana Nasya In The Management Of Suryavartha (Frontal Sinusitis). International Ayurvedic Medical Journal \{online\} 2021 \{cited August 2021\}

Available from: http://www.iamj.in/posts/images/upload/1654_1658.pdf 